НАУКОВИЙ ВІСНИК

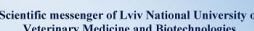

(1)

(4)

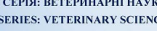

Том 22 № 100

2020
Науковий вісник Дьвівського національного університету ветеринарної медицини та біотехнологій імені С.3. Гжицького. Серія: Ветеринарні науки

Scientific Messenger of Lviv National University of Veterinary Medicine and Biotechnologies. Series: Veterinary sciences

UDC 636.09.611:636.09.618:636.2

\title{
Estrogen and progesterone endometrial cell receptors in cows with subclinical endometritis
}

\author{
T. P. Basarab ${ }^{1}$, V. Yu. Stefanyk ${ }^{1}$, M. Koziorowski ${ }^{2}$, K. Kozioł ${ }^{2}$, A. R. Pilip ${ }^{3}$ \\ ${ }^{1}$ Stepan Gzhytskyi National University of Veterinary Medicine and Biotechnologies Lviv, Lviv, Ukraine \\ ${ }^{2}$ Rzeszow University, Rzeszow, Republic of Poland \\ ${ }^{3}$ University of Alberta, Edmonton, Canada
}

Article info

Received 23.10.2020

Received in revised form 23.11.2020

Accepted 24.11.2020

Stepan Gzhytskyi National

University of Veterinary Medicine

and Biotechnologies,

Pekarska, Str., 50, Lviv

79010, Ukraine.

Tel.: +38-073-720-32-31

E-mail: basarabtaras@gmail.com

Rzeszow University, al. Rejtana

16c, 35-959 Rzeszów.

Republic of Poland

University of Alberta

116 St \& 85 Ave, Edmonton, Canada
Basarab, T. P., Stefanyk, V. Yu., Koziorowski, M., Koziol, K., \& Pilip, A. R. (2020). Estrogen and progesterone endometrial cell receptors in cows with subclinical endometritis. Scientific Messenger of Lviv National University of Veterinary Medicine and Biotechnologies. Series: Veterinary sciences, 22(100), 141-150. doi: 10.32718/nvlvet10024

Pathological processes that strongly affect the uterine endometrium lead to infertility and abortion. The most common of these pathologies are clinical and subclinical endometritis. Subclinical endometritis is characterized by endometrial inflammation in the absence of clinical signs of endometritis. In this study, we used uterine samples obtained from Ukrainian black-and-white dairy cows aged 4 to 7 years to compare the histology of the uterine endometrium and changes in estrogen- $\alpha(E R-\alpha)$, estrogen- $\beta$ (ER- $\beta)$ and progesterone (PgR) nuclear receptor sensitivity in cows with subclinical endometritis. Cows were separated based on cytological examination of the endometrium into a healthy group, or those presenting with subclinical endometritis. From these groups endometrial and epithelial tissue samples were obtained using biopsy forceps and an endoscope then analyzed using immunohistochemistry. Our results demonstrate that the sensitivity of ER- $\alpha$ and ER- $\beta$ is lower while PgR sensitivity is elevated in cows with subclinical endometritis compared to the healthy control group. Additionally, we observed markedly altered histological changes characterized by enlargement of uterine glands, epithelial desquamation, and infiltration of leukocytes. These results suggest that there are significant changes in the endometrium linked to the sensitivity of nuclear steroid hormone receptors that may also play an immunoregulatory role in cows with subclinical endometriosis. While the interaction of steroid hormones and immunoregulation in the uterus remains to be elucidated, it may provide key insights into the uterine immune response.

Key words: uterus, hormones, cow, immunohistochemistry, infertility.

\section{Чутливість рецепторів клітин ендометрію до естрогенів та прогестерону у корів хворих на субклінічний ендометрит}

\author{
Т. П. Басараб ${ }^{1}$, В. Ю. Стефаник ${ }^{1}$ М. Козіровський ${ }^{2}$, К. Козьол ${ }^{2}$, А. Р. Пилип ${ }^{3}$ \\ ${ }^{1}$ Львівський національний університет ветеринарної медицини та біотехнологій імені С. 3. Гэсииького, м. Львів, \\ Україна \\ ${ }^{2}$ Жешувський університет, Жешув, Республіка Польща. \\ ${ }^{3}$ Альбертський університет, Едмонтон, Канада
}

В основі патологічних процесів, щзо проходять у матиі приводять до неплідності та абортів, важливу роль відіграє ендометрій. Найбільш поширеними патологіями, щчо проходять у матиі є клінічний та субклінічний ендометрит. Субклінічний ендометрит характеризується запальним прочесом у ендометрії без клінічних ознак. Метою нашої роботи було проаналізувати гістологічні зміни та зміни чутливості ендометрію матки до естроген- $\alpha$ (ER- $\alpha$ ), естроген- $\beta$ (ER- $\beta$ ) та прогестерону (РgR), изо відбува- 
ються у матиі здорових корів та у корів за субклінічного ендометриту. Дослідження проводилось на двох групах корів української чорно-рябої молочної породи віком від 4 до 7 років. На основі цчитологічного дослідження ендометрію, корови були поділені на дві групи. Контрольну групу (К), шо включала клінічно здорових корів, та дослідну (Д), шо включала корів хворих на субклінічний ендометрит. Надалі проводили забір зразків за допомогою біопсійних щуипців та ендоскопу. Наші результати дають змогу більи глибоко зрозуміти процеси, шо відбуваються у ендометрії корів хворих на субклінічний ендометрит. Активність рецепторів ядер ЕR$\alpha$, ER- $\beta$ ma PgR спостерігали у епітелії ендометрію, епітелї маткових залоз та стромі ендометрію. Активність рецепторів ядер ER- $\alpha$ ma ER- $\beta$ була нижчою у корів з субклінічним ендометритом, ніж у корів контрольної групи. Активність рецепторів ядер РgR була вищою у корів хворих на субклінічний ендометрит, ніж у корів контрольної групи. На основі отриманих даних встановлено, щзо ендометрій хворих на субклінінчий ендометрит зазнає значних змін, щзо характеризується появою лейкоцитів, розииренням маткових залоз та ділянками десквамації епітелію. Зміни відбуваються на основі чутливості ядер ендометрію до рецепторів ЕR$\alpha$, ER- $\beta$ ma PgR. Чутливість ендометрію до гормонів є важливою у локальному захисті матки. В перспективі подальших досліджень слід вивчити експресію стероїдних гормонів та циитокінів у корів хворих на субклінічний ендометрит.

Ключові слова: матка, гормони, корова, імуногістохімія, неплідність.

\section{Вступ}

Ендометрій, що вкриває матку, відіграє важливу роль у фізіологічному перебігу статевого циклу, імплантації та підтриманні вагітності. Патологічні процеси, які можуть проходити у матці $є$ актуальною проблемою, що приводить до неплідності та абортів (Turner et al., 2012). Такі патологічні процеси впливають на метаболізм, що має прямий вплив на лактацію (LeBlanc, 2012).

Патології матки найчастіше діагностують у високо продуктивних корів. Гострий запальний процес у матці виявляють у 20-40 \% корів протягом семи діб після родів, ендометрит розвивається у $20 \%$ корів через двадцять діб після родів, а приблизно у $30 \%$ корів розвивається субклінічний ендометрит (Sheldon et al., 2009; Gilbert, 2016). За клінічним перебігом запальний процес, що проходить у матці, поділяють на клінічний та субклінічний ендометрит. Ці патології призводять до зниження відсотка запліднення при штучному осіменінні корів. Для успішного процесу запліднення та подальшого розвитку ембріону, матка повинна відповідати оптимальним умовам, а секрет матки має включати гормони, простагландини, енергетичні субстрати, білки та інші речовини (Abere \& Belete, 2016; Abdisa, 2018). Субклінічний ендометрит характеризується запаленням ендометрію без клінічних ознак та призводить до порушення відтворювальної функції корів (Sheldon et al., 2006).

Мікроорганізми, як правило, потрапляють у просвіт матки через відкритий канал шийки матки під час та після родів, та наявні там протягом декількох тижнів. Бактеріальне забруднення у післяродовий період $\epsilon$ причиною більшості запальних процесів матки (Sheldon et al., 2006). Основними збудниками, що виділені при ендометриті, були $E$. coli та Arcanobacterium pyogenes (Williams et al., 2005).

Матка корів здатна самостійно подолати інфекцію (LeBlanc, 2008). Розвиток інфекційного процесу залежить від імунної відповіді матки корів та від кількості мікроорганізмів. Вважається, що на інфекційний процес в матці має вплив ендокринний статус організму, оскільки клітини матки $є$ мішенню для прогестерону та естрогенів (Sheldon et al., 2006; Stormshak \& Bishop, 2008). Жовте тіло синтезує прогестерон, який пригнічує імунний захист матки. Поряд з імуносупресивною дією, прогестерон впливає на регулювання синтезу простагландинів (PGF2a) та імуномодулюючих цито- кінів (Sheldon et al., 2006). Загалом вважається, що висока концентрація прогестерону пригнічує скорочення міометрію, секрецію маткових залоз та фагоцитарну активність маткових нейтрофілів (LeBlanc, 2008). У корів 3 мікробним обсіменінням статевих шляхів спостерігають порушення розвитку домінантних фолікулів та, як наслідок, зниження концентрації естрадіолу у периферичній крові, що у свою чергу затримує овуляцію (Sheldon et al., 2018). Початкова імунна відповідь матки відбувається під впливом естрогенів, хоча механізм їх дії достеменно невідомий (LeBlanc, 2008). Встановлено, що у післяродовий період, у корів зустрічається метаболічний стрес, який приводить до порушення синтезу лютеїнізуючого гормону і затримання овуляції (Sheldon et al., 2018).

Субклінічний ендометрит діагностують на основі цитологічного дослідження змивів матки, за умови відсутності гнійних виділень 3 піхви (Kasimanickam et al., 2004; Sheldon et al., 2006). Цитологічне дослідження вагінальних мазків відбитків вважається провідною методикою діагностики субклінічного ендометриту як у умовах господарства, так і в лабораторіях, в основному, 3 міркувань простоти виконання та низької вартості методики (Pascottini et al., 2016).

Для більш точної діагностики було запропоновано гістологічне дослідження тканин матки корів із застосуванням біопсії ендометрію (Chapwanya et al., 2010). При оцінці матеріалу запропоновано звертати увагу на ендометрій в цілому, залози та епітелій (Bonnett et al., 1991). Ендометрит гістологічно характеризується десквамацією епітелію, інфільтрацією лейкоцитами, набряком (Bondurant, 1999; Kasimanickam et al., 2004; Sheldon et al., 2006). Хоча жоден діагностичний тест не можна вважати точним, гістологічне дослідження вважається золотим стандартом для діагностики змін ендометрію, тому що дозволяє безпосередньо візуалізувати зміни в тканинах матки (Pascottini et al., 2016). Підводячи підсумок, слід зазначити, що клітини ендометрію відіграють ключову роль у імунному захисті статевих шляхів, що також приводить до модуляції ендокринної функції організму. Клінічний та субклінічний ендометрит порушує циклічну активність яєчників після родів, продовжує лютеїнову фазу та зниження ймовірності запліднення. Внутрішньоматкові інфекції порушують функцію гіпоталамуса та гіпофіза (Sheldon et al., 2009).

Метою нашої роботи було проаналізувати гістологічні зміни та зміни чутливості ендометрію матки 
до естроген- $\alpha$ (ER- $\alpha)$, естроген- $\beta$ (ER- $\beta)$ та прогестерону $(\mathrm{PgR})$, що відбуваються у матці здорових корів та у корів при субклінічному ендометриті.

\section{Матеріал і методи досліджень}

Дослідження проводилось у ПСП “Шпанівське” Рівненського району Рівненської області, на двох групах корів української чорно-рябої молочної породи віком від 4 до 7 років. Діагноз був встановлений на основі цитологічного дослідження клітин ендометрію (Kasimanickam et al., 2004; Sheldon et al., 2006), після чого, корови були поділені на дві групи. Контрольна група (К) включала п'ятнадцять $(\mathrm{n}=15)$ клінічно здорових корів у перший день після овуляції. Дослідна група (Д) включала п'ятнадцять $(\mathrm{n}=15)$ корів 3 субклінічним ендометритом.

Зразки для цитологічного дослідження відбирали за допомогою цитологічної щіточки, ендоскопу EG$530 \mathrm{NW}$ (Fujifilm, Японія) діаметром 5,9 мм та робочою довжиною 1100 мм та процесором ЕРХ-2500 (Fujifilm, Японія). Матеріал поміщали на предметне скло шляхом колових рухів цитологічної щіточки, фіксували та фарбували за допомогою набору реагентів LEUCODIFF 200 (Erba Lachema s.r.o., Чехія). Цитологічну оцінку проводили під мікроскопом Leica DM500 (Leica, Німеччина), при збільшенні 400x.

Забір зразків біопсії проводили за допомогою біопсійних щипців, ендоскопу EG-530 NW (Fujifilm, Японія) діаметром 5,9 мм та робочою довжиною 1100 мм та процесором ЕРX-2500 (Fujifilm, Японія). Після забору, біопсійний матеріал поміщали у 4\% параформальдегіді і фіксували протягом 24 годин. Після фіксації зразки були регідратовані і поміщені у Paraplast Plus (Sigma-Aldrich, Швейцарія) при температурі 56-57 ${ }^{\circ} \mathrm{C}$.

Для отримання зразків товщиною $5 \mu$ м використовували мікротом Leica RM2265 (Leica, Німеччина). Для гістологічного дослідження, зразки були депарафінізовані, регідратовані та зафарбовані барвниками гематоксиліном та еозином. Фінальною стадією було накладання DPX (Buchs, Швейцарія) та покрівельних скелець.

Для імуногістохімічного дослідження зразки були депарафінізовані та регідратовані. Демаскування антигенів проводили кип'ятінням протягом двох хвилин у $0.001 \mathrm{M} \mathrm{розчині} \mathrm{цитратного} \mathrm{буферу} \mathrm{(рН} \mathrm{6.0).} \mathrm{Після}$ інкубування протягом 60 хвилин, зразки були промиті у розчині фосфатного буферу (PBS). Ендогенну пероксидазу блокували за допомогою реагенту Peroxidase Blocking Reagent ready-to-use (Dako, Denmark) протягом 10 хвилин 3 наступним застосуванням бичачого сироваткового альбуміну (BSA) у PBST (1 мл Tween 20 (Sigma, США) у 1 літрі 1xPBS) протягом 1 години, для блокування неспецифічних зав'язків. Зразки були промиті у PBST з подальшою інкубацією при $4{ }^{\circ} \mathrm{C}$ протягом ночі. Були застосовані первинні антитіла до естроген- $\alpha$ (ER- $\alpha)$ (1:35 Monoclonal Mouse Anti-Human Estrogen Receptor $\alpha$, isotype IgG1, clone 1D5, Dako, Данія), естроген- $\beta$ (ER- $\beta$ ) (1:15 Monoclonal Mouse Anti-Human Estrogen Receptor $\beta 1$, isotype IgG2a, clone PPG5/10, Dako, Данія), прогестерон (PgR) (1:20 Mono- clonal Mouse Anti-Human PR Receptor isotype IgG2 $\alpha$ Dako, Данія) розведені у $2 \%$ BSA у PBST. Для негативного контролю, негативні антитіла не застосовувались.

Наступного дня зразки промивали протягом 5 хвилин у PBST. Були застосовані вторинні антитіла (Dako Real EnVision / HRP, Rabbit / Mouse (ENV), ready-touse, Dako, Данія) з подальшою інкубацією 2 години в темному місці при кімнатній температурі. Після дворазового промивання у PBST і одного промивання у PBS, додали 1 мл Substrate Buffer $+20 \mu \mathrm{DAB}+$ Chromogen (Dako REAL EnVision Detection System, Peroxidase / DAB + Rabbit / Mouse Code K5007, Dako, Данія) та інкубували протягом 5 хвилин. Реакцію переривали дистильованою водою 3 наступною дегідратацією. Фінальною стадією було накладання DPX (Distyrene Plasticiser and Xylene; Buchs, Швейцарія) та покрівельних скелець.

Фотореєстрацію препаратів проводили методом світлової мікроскопії, використовували мікроскоп Leica DM-2500 (Leica, Швейцарія) та фотокамеру Leica DFC 450C (Leica, Німеччина) і програмне забезпечення Leica Application Suite Version 4.4.

Для оцінки інтенсивності імуногістохімічної реакціï, використовували програмне забезпечення ImageJ (National Institutes of Health, Bethesda, MD, США). Були позначені імунопозитивні клітини та визначений їхній рівень сірого (GL). Імуногістохімічну реакцію виражали як відносну оптичну щільність (ROD) i підраховували за допомогою формули (Smolen, 1990):

\section{ROD $=\frac{\text { OD specimen }}{\text { OD background }}=\frac{\log (\text { GLblank } / \text { GLspecimen })}{\log (\text { GLblank/GLbackground })}$}

де GL - це інтенсивність сірого зафарбованих ділянок зразків (specimen) та незафарбованих ділянок (background), інтенсивність сірого, визначений у зразках без дослідного матеріалу (blank).

Значення виражені як М (середнє арифметичне) $\pm \mathrm{SD}$ (стандартне відхилення). Статистичну обробку даних проводили за допомогою SPSS (IBM, США). У випадках, коли тест Шапіро-Уілка вказав на нормальний розподіл даних, вірогідність показників оцінювали за t-критерієм Стьюдента. За ненормального розподілу використовували критерій Манна-Уітні. Статистично значущими вважали відмінності за $\mathrm{P}<0,05$.

\section{Результати}

Імуногістохімічний аналіз тканин матки корів проводили на основі визначення чутливості клітин мішеней ендометрію до естрогенів (ER- $\alpha$, ER- $\beta$ ) та прогестерону (PgR).

Було встановлено активність рецепторів ядер ER- $\alpha$ (рис. 1) у епітелії ендометрію, епітелії маткових залоз, і стромі ендометрію. У клінічно здорових корів активність реакції була сильнішою у епітелії ендометрію та незначно у стромі ендометрію, ніж у корів при субклінічному ендометриті. Активність реакції епітелію маткових залоз була однаковою у корів при субклінічному ендометриті та у клінічно здорових корів. 
Отримані результати вказують (рис. 2), що у ендометрії клінічно здорових корів, відносна оптична щільність рецепторів ER- $\alpha$ становила 5,09 $\pm 0,30$, а у

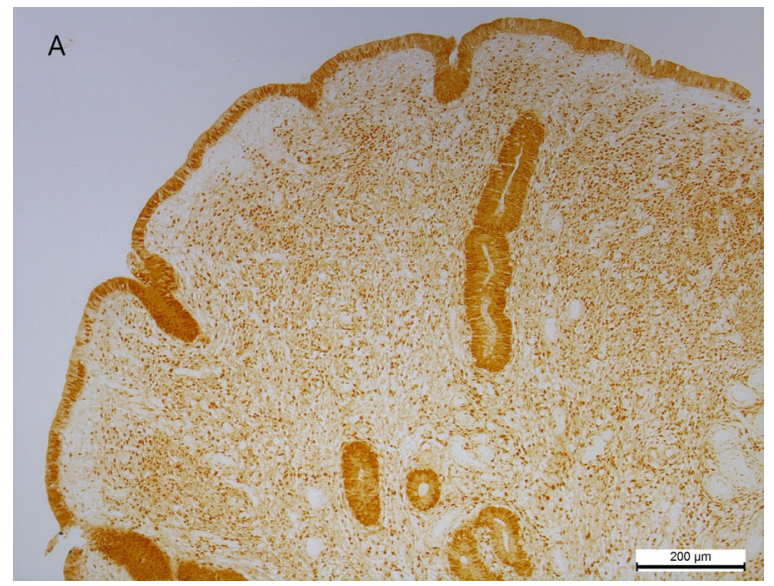

корів хворих на субклінічний ендометрит, відносна оптична щільність знизилась до 4,99 $\pm 0,42(\mathrm{P}<0,43)$.

Рис. 1. Імуногістохімічна реакція з використанням антитіл ER- $\alpha$ ендометрію здорових корів (A) та корів хворих на субклінічний ендометрит (B)

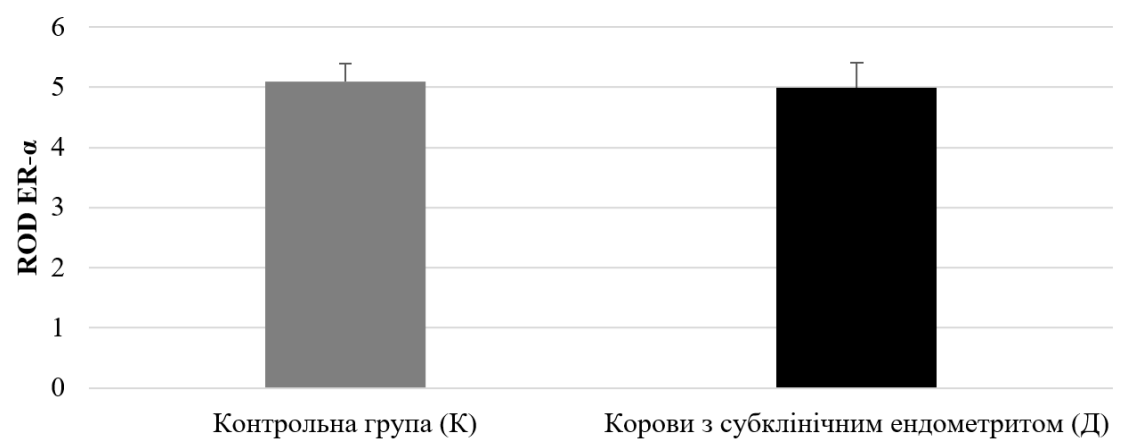

Рис. 2. Відносна оптична щільність рецепторів ER- $\alpha$ у ендометрії здорових корів (K) (n=15) та у корів хворих на субклінічний ендометрит (Д) $(\mathrm{n}=15)$

Активність рецепторів ядер ER- $\beta$ (рис. 3) спостерігали у епітелії ендометрію, епітелії маткових залоз і стромі ендометрію. У клінічно здорових корів активність реакції була сильнішою у стромі ендометрію, та у епітелії ендометрію. Активність реакції епітелію маткових залоз була однакова у клінічно здорових корів та у корів за субклінічного ендометриту.
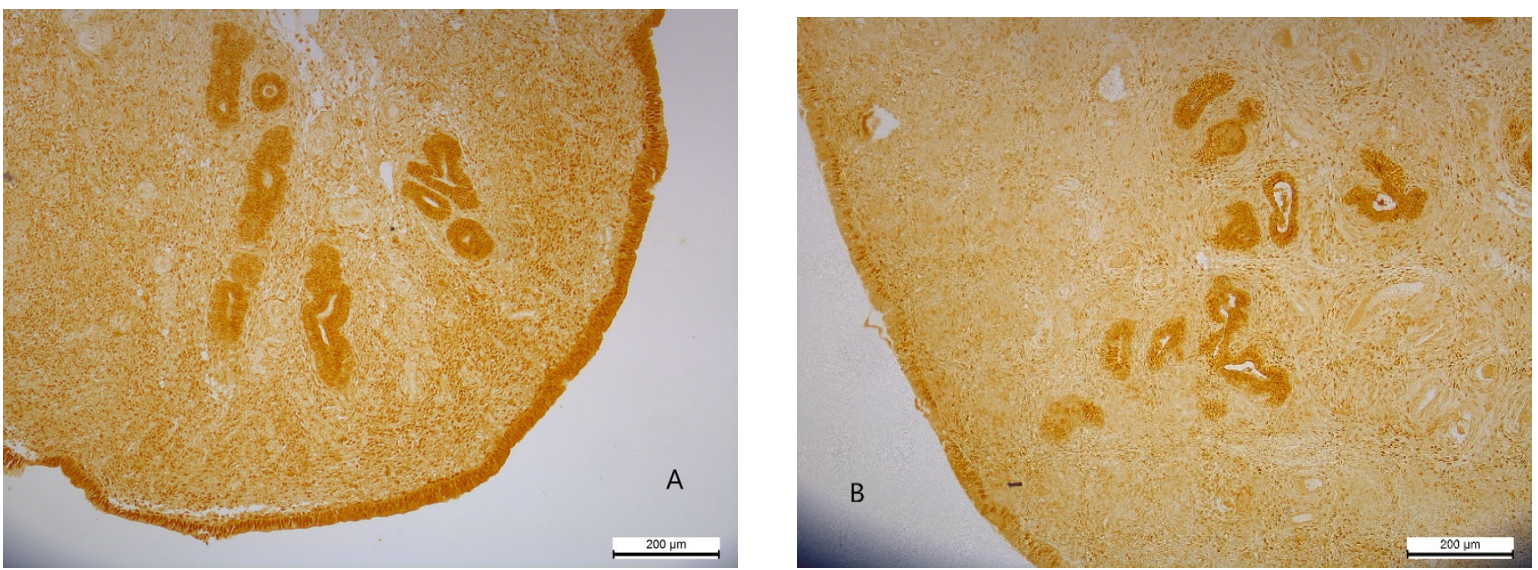

Рис. 3. Імуногістохімічна реакція з використанням антитіл до ER- $\beta$ ендометрію здорових корів (А) та корів хворих на субклінічний ендометрит (B)

У результаті проведених досліджень встановлено (рис. 4), що у ендометрії клінічно здорових корів, відносна оптична щільність рецепторів ER- $\beta$ стано- вила $3,57 \pm 0,48$, а у корів хворих на субклінічний ендометрит, відносна оптична щільність знизилась до $3,32 \pm 0,33(\mathrm{P}<0,11)$. 


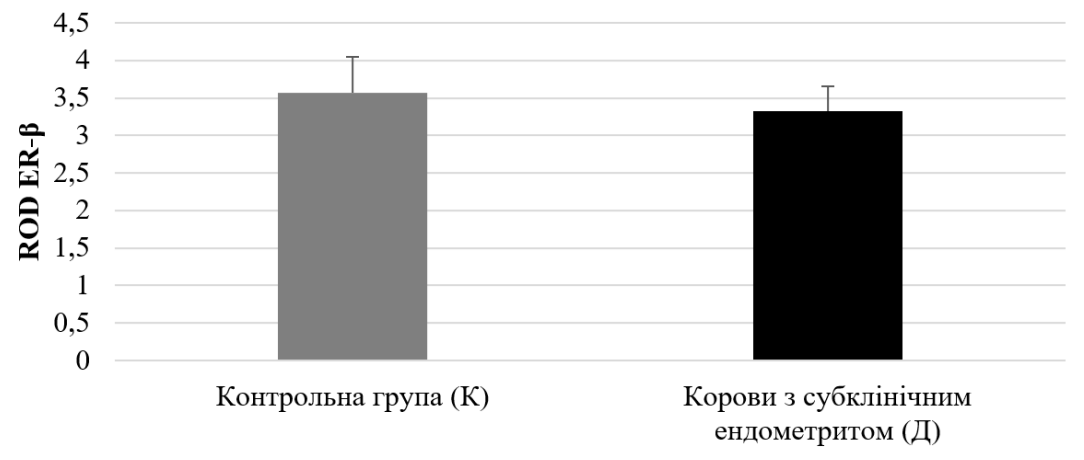

Рис. 4. Відносна оптична щільність рецепторів ER- $\beta$ у ендометрії здорових корів $(K)(n=15)$ та у корів хворих на субклінічний ендометрит (Д) $(\mathrm{n}=15)$.

Отримані результати по рецепторах ядер PgR (рис. 5) вказують, що активність у епітелії ендометрію, епітелії маткових залоз і стромі ендометрію була низькою. Активність реакції у клінічно здорових корів в основному спостерігали у епітелії маткових
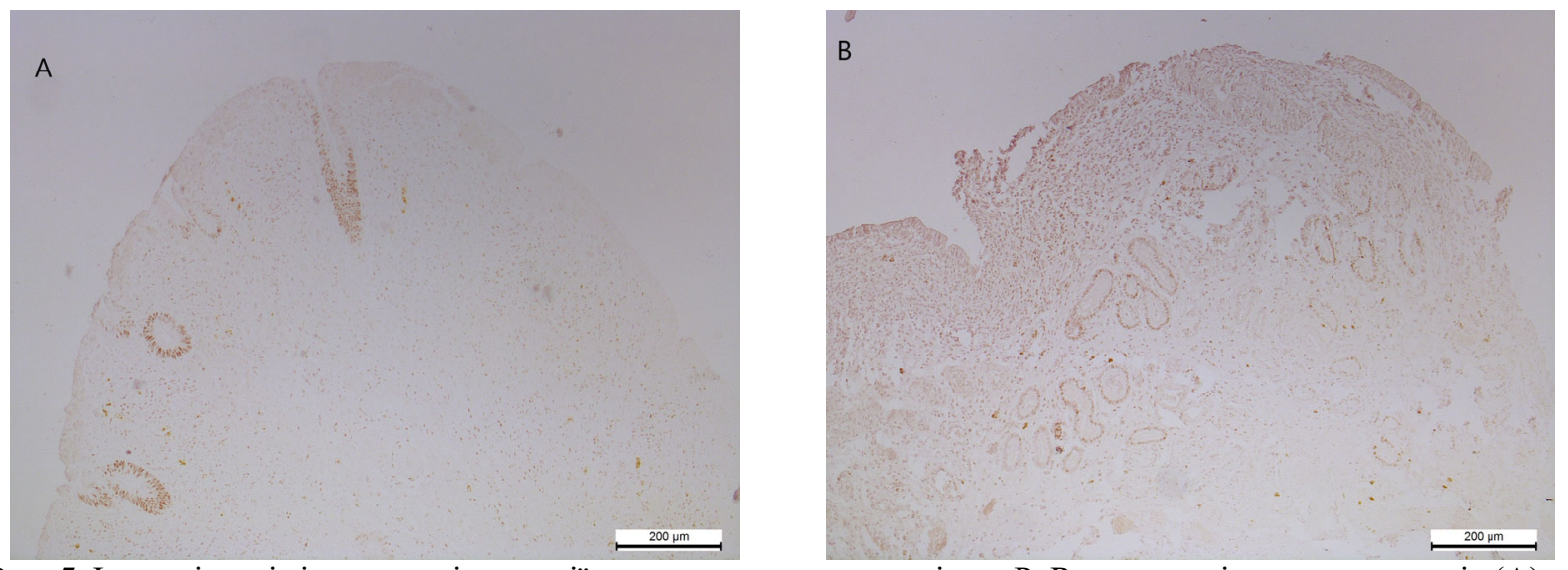

Рис. 5. Імуногістохімічна реакція реакції з використанням антитіл до $\mathrm{PgR}$ ендометрію здорових корів (А) та корів хворих на субклінічний ендометрит (B)

Встановлено (рис. 6), що у ендометрії клінічно здорових корів, відносна оптична щільність рецептоpiв PgR складала $1,40 \pm 0,41$, а у корів хворих на суб- залоз та у стромі. У корів хворих на субклінічний ендометрит активність реакції була сильнішою у епітелії слизової оболонки, епітелії маткових залоз і стромі ендометрію, ніж у клінічно здорових корів. клінічний ендометрит, відносна оптична щільність зросла до $13,72 \pm 4,61(\mathrm{P}<0,001)$.

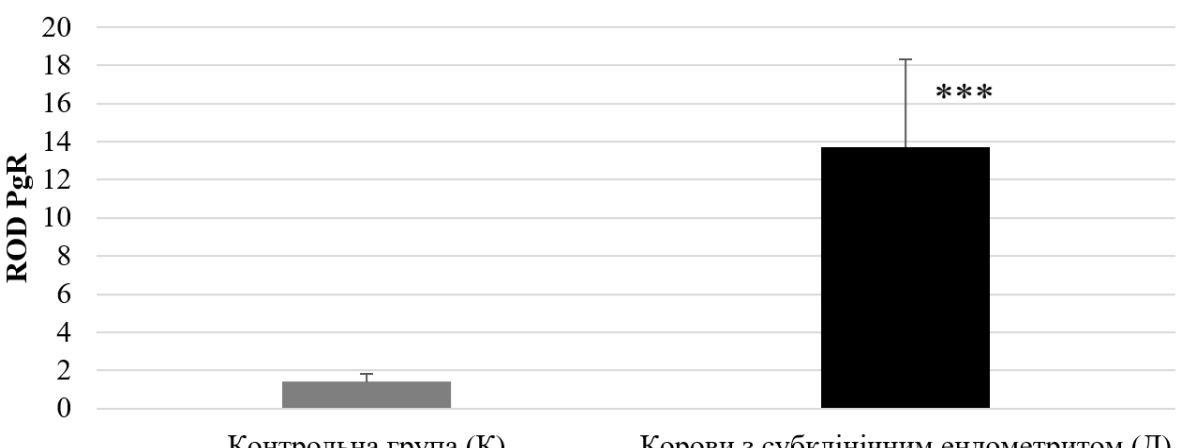

Рис. 6. Відносна оптична щільність рецепторів $\mathrm{PgR}$ у ендометрії здорових корів $(\mathrm{K})(\mathrm{n}=15)$ та у корів хворих на субклінічний ендометрит (Д) $(\mathrm{n}=15)$

Примітки: ступінь вірогідності порівняно з контрольною (К) групою *** $-\mathrm{P}<0,001$

При проведенні гістологічного дослідження тканин матки, у клінічно здорових корів спостерігали (рис. 7) одношаровий циліндричний епітелій. Ядра епітелію розташовані у базальній частині клітини, 
зи були розширеними, а просвіт здебільшого заповнений секретом. Епітелій маткових залоз одношаровий циліндричний. Ядра епітелію маткових залоз розташовані у базальній частині клітини, апікальна частина була заповнена цитоплазмою.

У корів при субклінічному ендометриті (рис. 8) спостерігали одношаровий циліндричний епітелій, 3 ділянками десквамації. Ядра епітелію були розташовані у базальній частині клітини, апікальна частина була заповнена цитоплазмою. У стромі, під базальною мембраною та у епітелії спостерігали інфільтрацію лейкоцитами. У стромі виявили поодинокі, розширені маткові залози, секрет у просвіті залоз був відсутній. Епітелій маткових залоз одношаровий циліндричний. Ядра епітелію маткових залоз розташовані у базальній частині клітини, апікальна частина була заповнена цитоплазмою.
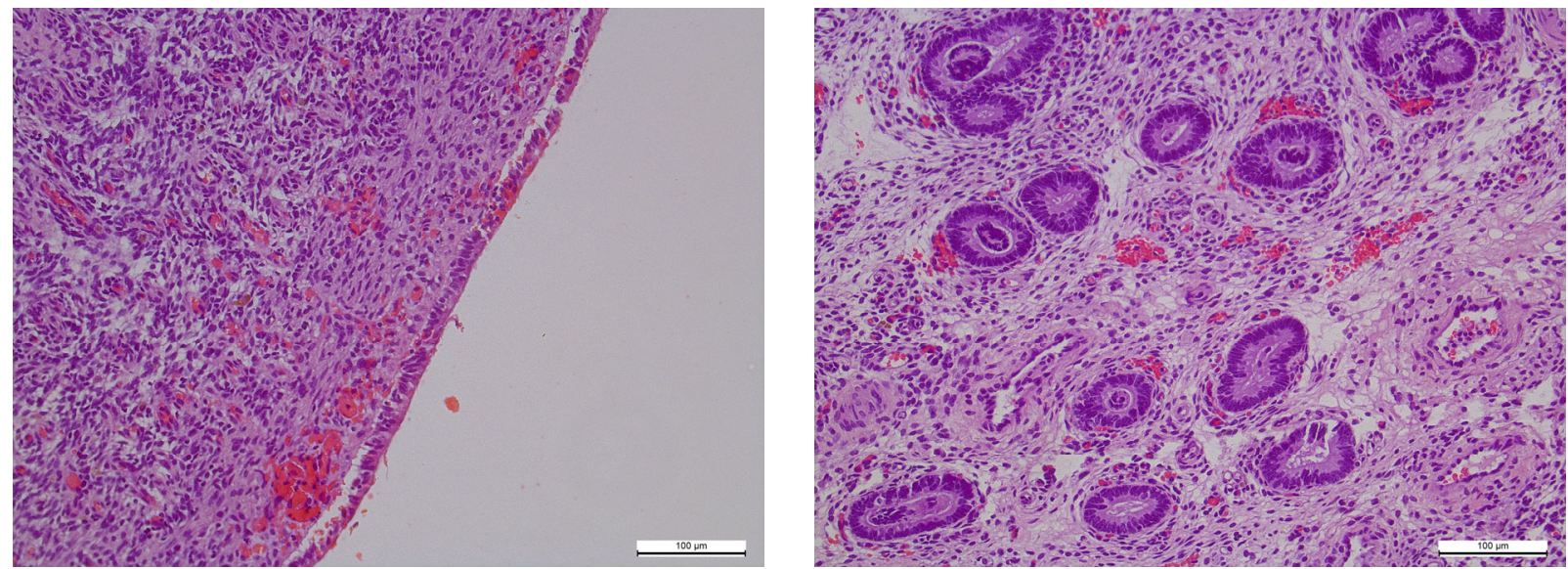

Рис. 7. Ендометрій клінічно здорових корів. Фарбування гематоксиліном та еозином
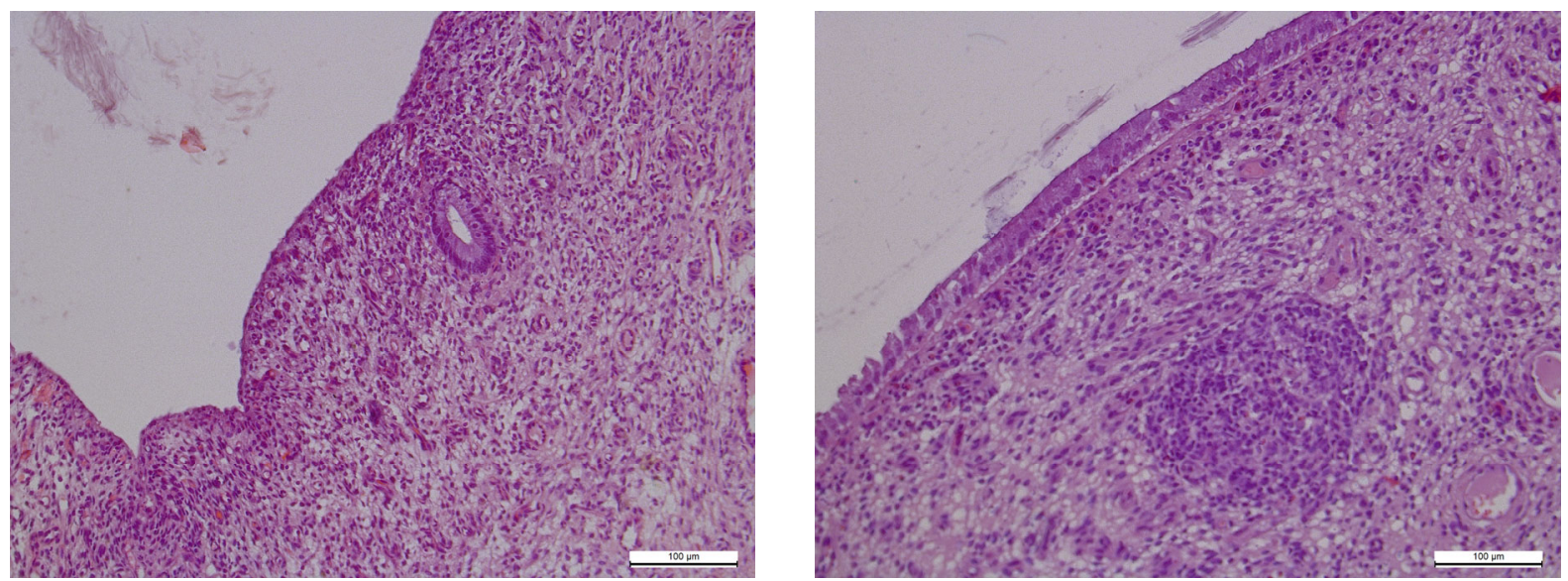

Рис. 8. Ендометрій корів при субклінічному ендометриті. Фарбування гематоксиліном та еозином

\section{Обговорення}

Продуктивність корів $є$ важливою економічною складовою ведення сучасного господарства. Визначальним фактором, що впливає на продуктивність корів $€$ репродуктивна функція. Регулярне отримання нащадків залежить від фізіологічного функціонування репродуктивного тракту тварини. Для цього важливими $€$ функціонування яєчників та гіпоталамогіпофізарної системи в цілому, що забезпечує фізіологічний перебіг статевого циклу, імплантацію, підтримку ембріону та плода протягом вагітності, відновлення матки після отелення (Abdisa, 2018).

У нашому дослідженні ми порівнювали гістологічні зміни та активність імуногістохімічної реакції рецепторів ядер ER- $\alpha$, ER- $\beta$, PgR у ендометрії матки здорових корів та корів хворих на субклінічний ендометрит.
На основі отриманих даних можна констатувати про наявність лейкоцитів у ендометрії матки корів хворих на субклінічний ендометрит, а саме: у стромі, під базальною мембраною та у епітелії. Інфільтрація лейкоцитами $є$ відповіддю імунної системи на дію інфекційних агентів, за даними (Sheldon et al., 2006), найчастіше такими збудниками $є$ A. pyogenes, Fusobacterium necrophorum, Prevotella species and E. coli. Слід зазначити, що при субклінічному ендометриті, лейкоцити у тканинах матки $є$ характерним явищем. Нейтрофіли, що є одним 3 видів лейкоцитів, виявляли при гістологічному дослідженні тканин матки корів та зазначали їх нерівномірний розподіл, із значно більшим їх числом у глибоких шарах та зменшенням їх кількості до епітелію ендометрію. Така міграція цих клітин, з периферійного кровообігу до місця ураження, є важливим етапом імунної відповіді матки (Pascottini et al., 2016). Слід зазначити, що ак- 
тивність нейтрофілів у тканинах сильніша, ніж у нейтрофілів циркулюючих у периферійній крові. Активація їхньої функції відбувається під дією цитокінів (Bondurant, 1999). Окремі автори встановили зростання кількості лейкоцитів поруч із зростанням концентрації цитокінів (TNF- $\alpha$, IL-6, IL-10) у периферійній крові та у змивах маткового слизу (Brodzki et al., 2015). Лейкоцити також виявляли на апікальній поверхні епітеліоцитів, що було підтверджено методом скануючої електронної мікроскопії (Stefanyk et al., 2010). Надалі, нейтрофіли виявляють, використовуючи метод цитологічного дослідження клітин ендометрію, при постановці діагнозу на субклінічний ендометрит у корів (Kasimanickam et al., 2004).

Отримані нами дані, свідчать про те, що у корів хворих на субклінічний ендометрит, спостерігали обширні ділянки десквамації епітелію, що збігається 3 раніше опублікованими результатами (Balym, 2014). Порушення цілісності епітелію відбувається внаслідок місцевої запальної реакції, що є відповіддю на дію мікроорганізмів. Існують гіпотези про те, що зміни, які проходять в ендометрії, порушують гормональний баланс і призводять до негативного впливу на спермії при осіменінні, заплідненні та на подальшу імплантацію зиготи (Sheldon et al., 2009). На основі цього можна констатувати, що структура епітелію та його цілісність тісно пов'язана 3 репродуктивною функцією корів.

У жуйних ендометрій зазнає значного впливу та змін під дією естрадіолу та прогестерону (Хiao \& Goff, 1998). Фізіологічна функції репродуктивної системи самки відбувається під дією гормонів яєчників, через внутрішньоклітинні білки. Ці білки відповідають за розпізнавання та трансдукцію гормонального сигналу (Meikle, 2000). Були оприлюднені дані (Boos et al., 1996; Kimmins \& MacLaren, 2001; Robinsonet al., 2001; Saruhan et al., 2009) про наявність рецепторів естрогену та прогестерону у епітелії та стромі матки корів, що збігається з нашими результатами. Вважається, що активність рецепторів до естрогенів та прогестерону у тканинах матки регулюється концентрацією естрогенів та прогестерону у сироватці крові (Saruhan et al., 2009). Дослідження проведені на кобилах вказують, що естрадіол посилює експресію рецепторів статевих гормонів, а прогестерон пригнічує (Aupperle et al., 2000). Також, у регуляції активності рецепторів та у їх поширення в тканинах бере участь паракринний фактор (Kimmins \& MacLaren, 2001).

У корів з патологією матки після родів поруч із затримкою росту фолікулів спостерігали зниження концентрації естрогенів у крові (Sheldon et al., 2009). Важливим є повідомлення про те, що активність рецепторів ER була вищою за фолікулярної фази і пояснюється посиленням синтезу естрогенів (Saruhan et al., 2009). Разом з тим в нашому дослідженні встановили незначне зниження відносної оптичної щільності ER- $\alpha$ та ER- $\beta$ у тканинах матки, у корів хворих на субклінічний ендометрит. Окремі автори встановили посилення імунної відповіді матки при зростанні концентрації естрогенів (Ramadan et al., 1997). Дія цих гормонів покращує кровопостачання матки, міграцію лейкоцитів 3 кров'яного русла до просвіту матки та посилює утворення маткового секрету, що $є$ важливим етапом у захисті матки та бар'єром від інфекційних агентів (Azawi, 2008). У дослідженні проведеному на свиноматках, встановили інтенсивне фарбування ER- $\alpha$ у тканинах матки протягом різних стадій статевого циклу. Автори припускають про наявність зв'язку між концентрацією естрогенів та прогестерону у периферичній крові та кількістю позитивних ER$\alpha$ клітин у тканинах матки. У цьому ж дослідженні встановлено, що різні тканини матки можуть по різному реагувати на однакову концентрацію стероїдних гормонів. Загалом, прийнято вважати, що у ссавців естрогени посилюють, а прогестерон послаблює активність ER- $\alpha$ (Sukjumlong et al., 2003).

Опубліковані дані (Wang et al., 2000) вказують, що лише ER- $\beta$ - не відіграє значної ролі в матці. Взаємодія ER- $\alpha$ та ER- $\beta$ має вирішальний вплив на фізіологічні зміни епітеліальних клітин. Інші публікації вказують, що у приматів, ER- $\beta$ бере активну участь у змінах ендометрію, що виникають під час імплантації ембріона (Hapangama et al., 2015). Незначне зниження концентрації ER- $\beta$ у хворих на субклінічний ендометрит корів, може бути пов'язане 3 неможливістю імплантації ембріона та в подальшому 3 відсутністю вагітності.

У результаті проведених досліджень не було виявлено статистичної вірогідності рецепторів ER- $\alpha$ та ER- $\beta$ між коровами $з$ фізіологічним перебігом статевого циклу та коровами з субклінічним ендометритом. Підтвердження цьому може бути дослідження методом qPCR, в якому теж не встановили статистичної вірогідності ER- $\alpha$ між здоровими коровами та коровами хворими на субклінічний ендометрит. В цій публікації автори дійшли висновку, що ER- $\alpha$ не має впливу на патологію матки, більше того, активність ER- $\alpha$ не має впливу на збільшення кількості лейкоцитів в матці (Johnson et al., 2015). Функція ER- $\alpha$ у тканинах матки може полягати у стимуляції секреції залозами ендометрію та передачі інформації про концентрацію естрадіолу у плазмі крові іншим клітинами ендометрію за допомогою паракринної взаємодії. В цьому досліджені також вказано, що ER- $\alpha$ регулюється на пост-транскрипційному рівні (Robinson et al., 2001). У дослідженні на людях подано інформацію, що ER- $\alpha$ бере участь у проліферації клітин ендометpiю (Geisert et al., 1992).

Нами встановлено, що активність рецепторів ER- $\alpha$ та ER- $\beta$ зберігалась у стромі ендометрію та у епітелії маткових залоз здорових та хворих на субклінічний ендометрит корів. Це наштовхує нас на думку, що загалом естрогени не беруть активної участі у змінах, що відбуваються у матці при субклінічному перебігу ендометриту. Також це підтверджується відсутністю вірогідних змін відносної оптичної щільності ER- $\alpha$ та ER- $\beta$ між здоровими коровами та коровами хворими на субклінічний ендометрит.

Вище було вже зазначено, що взаємодія ER- $\alpha$ та ER- $\beta$ є важливю у фізіологічному функціонуванні епітелію (Wang et al., 2000). Також, зазначається, що 
ER- $\alpha$ та ER- $\beta$ може мати протилежну дію. Зокрема, ER- $\beta$ у відповідь на дію $17 \beta$ - естрадіол може знижувати активність ER- $\alpha$. Експресія ER- $\beta$ може знижуватись через $17 \beta$ - естрадіол, що діє через ER- $\alpha$ (Hapangama et al., 2015). Нами встановлено одночасне зниження ER- $\alpha$ та ER- $\beta$ у корів хворих на субклінічний ендометрит. Це може свідчити про регуляторний зв'язок між ER- $\alpha$ та ER- $\beta$ та на нашу думку, потребує більш глибокого дослідження.

У дослідженні на кобилах показано, що естрадіол має значний вплив на диференціацію клітин строми і може спонукати до стромально-епітеліальної взаємодії. Клітини строми можуть впливати на диференціацію клітин епітелію через регуляцію гормональних рецепторів (Aupperle et al., 2000). Нами встановлено, що активність рецепторів ER- $\alpha$ та ER- $\beta$ у стромі майже не змінювалась, у епітелії просвіту матки активність знижувалась у корів з субклінічним ендометритом та була високою у епітелії клінічно здорових корів. Ці зміни та факт, що епітелій зазнає значних змін протягом еструсу, можуть підтверджувати міцний зв'язок між клітинами строми та епітелію, та впливом клітин строми на чутливість епітелію просвіту матки до естрогенів. Естрогени можуть посилювати імунну відповідь матки та впливають на диференціацію клітин (Ramadan et al., 1997; Aupperle et al., 2000). У корів при субклінічному ендометриті спостерігали зниження активності рецепторів ER- $\alpha$ та ER- $\beta$ y епітелії просвіту матки (ділянки без десквамації). На основі цього, можемо констатувати важливість естрогенів у локальній імунній відповіді та у диференціації епітелію.

Нами встановлено відсутність статистично вірогідних змін відносної оптичної щільності ER- $\alpha$ та ER- $\beta$ між здоровими коровами та коровами хворими на субклінічний ендометрит. В той самий час, активність між різними клітинами матки була різною. Це узгоджується 3 дослідженням на свиноматках, де наголошується на тому, що різні тканини матки по різному реагують на дію стероїдних гормонів (Sukjumlong et al., 2003).

У корів з фізіологічним перебігом статевого циклу активність рецепторів PgR була вищою у епітелії глибоких маткових залоз і знижувалась до просвіту матки, що збігається з попередніми дослідженнями (Kimmins \& MacLaren, 2001; Bridges et al., 2012). Taкож, були отримані дані, які вказують на зниження активності рецепторів PgR в епітелії матки. На думку автора це відбувається за рахунок посилення синтезу простагландинів (PGF2 $\alpha$ ), що $є$ важливим етапом у лізисі жовтого тіла (Geisert et al., 1992).

У свою чергу, підвищення активності PgR приводить до посилення синтезу прогестерону (Bridges et al., 2012). Наші результати вказують, що у корів за субклінічного ендометриту, спостерігали значне зростання $(\mathrm{P}<0,001)$ активності рецепторів PgR у всіх тканинах ендометрію. Це дає змогу припустити, що прогестерон послаблює імунну відповідь матки у корів хворих на субклінічний ендометрит. Імуносупресивну дію прогестерону також підтверджували тим, що у жуйних внутрішньоматкові інфекції в основному виявляють після формування першого післяродового жовтого тіла. В той час, як після родів, за базального рівня прогестерону, матка $\epsilon$ стійкою до інфекцій (Azawi, 2008). Згідно опублікованої інформації, прогестерон може стимулювати і пригнічувати проліферацію клітин матки, проте механізм дії вивчений не повністю. Внутрішньоклітинні білки-рецептори прогестерону регулюються прогестероном, отже можуть брати участь у його дії на клітини рецептори (Geisert et al., 1992). У нашому та попередньому дослідженні в здорових корів спостерігали вищу інтенсивність імуногістохімічної реакції у маткових залозах та стромі ендометрію, тоді як епітелій просвіту матки мав слабку реакцію (Robinson et al., 2001). В цьому ж дослідженні було висунуто гіпотезу про те, що зміни активності прогестеронових рецепторів регулюються посттранскриптаційним контролем (Robinson et al., 2001). Поряд зі зростанням (Р <0,001) відносної оптичної щільності рецепторів прогестерону у корів хворих на субклінічний ендометрит, активність реакції спостерігали у епітелії просвіту матки, епітелії маткових залоз та у стромі. На основі цього, можемо припустити, що прогестерон відіграє важливу роль у змінах які відбуваються в матці у корів хворих на субклінічний ендометрит.

Прогестерон діє через ядерні білки-рецептори прогестерону (Graham \& Clarke, 1997). Активність прогестерону в клітинах матки залежить від попередньої підготовки цих клітин рецепторами ER- $\alpha$. Прикладом цієї дії є вплив естрогенів у фолікулярну фазу на ендометрій, що в подальшому посилює чутливість тканин матки до прогестерону у лютеїнову фазу (Lee \& Kim, 2014; Patel et al., 2015). Як уже зазначалось, естрогенові рецептори не мають прямого впливу на перебіг субклінічного ендометриту у корів. Але ми допускаємо думку, що відсутність значного зниження активності естрогенових рецепторів у корів хворих на субклінічний ендометрит посилює дію прогестерону на тканини матки хворих корів. Отже, цілком ймовірним $\epsilon$ той факт, що ER- $\alpha$ та ER- $\beta$ мають непрямий вплив на локальну імуносупресію у матці.

У результаті отриманих даних встановлено, що у хворих на субклінічний ендометрит корів, ендометрій зазнає значних змін. Це відбуваються внаслідок зміни чутливості ендометрію до стероїдних гормонів. Вважаємо, що чутливість ендометрію до стероїдних гормонів відіграє важливу роль у локальному імунному захисті матки. В подальшому слід більш глибоко вивчити взаємозв'язок гормонів та локальної імунної відповіді матки.

\section{References}

Abdisa, T. (2018). Review on the reproductive health problem of dairy cattle. J Dairy and Vet. Sci, 5(1), 112. doi: 10.19080/JDVS.2018.05.555655.

Abere, T., \& Belete, H. (2016). Infections of the uterus on postpartum cows. J. Reprod. Infertil, 7(2), 34-40.

Aupperle, H., Özgen, S., Schoon, H. A., Schoon, D., Hoppen, H. O., Sieme, H., \& Tannapfel, A. (2000). Cyclical endometrial steroid hormone receptor expres- 
sion and proliferation intensity in the mare. Equine veterinary journal, 32(3), 228-232. doi: 10.2746/042516400776563554.

Azawi, O. I. (2008). Postpartum uterine infection in cattle. Animal reproduction science, 105(3-4), 187-208. doi: 10.1016/j.anireprosci.2008.01.010.

Balym, Yu. P. (2014). Morfometrychni pokaznyky endometriiu koriv pislia kompleksnoho likuvannia hniino-kataralnoho endometrytu $\mathrm{z}$ zastosuvanniam biostymuliatora seleran. Visnyk Sumskoho natsionalnoho ahrarnoho universytetu. Seriia: Veterynarna medytsyna, 6, 184-185 (in Ukrainian).

Bondurant, R. H. (1999). Inflammation in the bovine female reproductive tract. Journal of animal science, 77(2), 101-110. doi: 10.2527/1999.77suppl_2101x.

Bonnett, B. N., Miller, R. B., Etherington, W. G., Martin, S. W., \& Johnson, W. H. (1991). Endometrial biopsy in Holstein-Friesian dairy cows. I. Technique, histological criteria and results. Canadian Journal of Veterinary Research, 55(2), 155. URL: https://pubmed.ncbi.nlm.nih.gov/1884295.

Boos, A., Meyer, W., Schwarz, R., \& Grunert, E. (1996). Immunohistochemical assessment of oestrogen receptor and progesterone receptor distribution in biopsy samples of the bovine endometrium collected throughout the oestrous cycle. Animal Reproduction Science, 44(1), 11-21. doi: 10.1016/0378-4320(96)01492-3.

Bridges, G. A., Mussard, M. L., Pate, J. L., Ott, T. L., Hansen, T. R., \& Day, M. L. (2012). Impact of preovulatory estradiol concentrations on conceptus development and uterine gene expression. Animal Reproduction Science, 133(1-2), 16-26. doi: 10.1016/j.anireprosci.2012.06.013.

Brodzki, P., Kostro, K., Krakowski, L., \& Marczuk, J. (2015). Inflammatory cytokine and acute phase protein concentrations in the peripheral blood and uterine washings of cows with subclinical endometritis in the late postpartum period. Veterinary research communications, 39(2), 143-149. doi: 10.1007/s11259-0159635-4.

Chapwanya, A., Meade, K. G., Narciandi, F., Stanley, P., Mee, J. F., Doherty, M. L., \& O'farrelly, C. (2010). Endometrial biopsy: a valuable clinical and research tool in bovine reproduction. Theriogenology, 73(7), 988-994. doi: 10.1016/j.theriogenology.2009.11.015.

Geisert, R. D., Morgan, G. L., Short, E. C., \& Zavy, M. T. (1992). Endocrine events associated with endometrial function and conceptus development in cattle. Reproduction, fertility and development, 4(3), 301-305. doi: $10.1071 /$ rd9920301.

Gilbert, R. O. (2016). Management of reproductive disease in dairy cows. Veterinary Clinics: Food Animal Practice, 32(2), 387-410. doi: 10.1016/j.cvfa.2016.01.009.

Graham, J. D., \& Clarke, C. L. (1997). Physiological action of progesterone in target tissues. Endocrine reviews, 18(4), 502-519. doi: 10.1210/edrv.18.4.0308.

Hapangama, D. K., Kamal, A. M., \& Bulmer, J. N. (2015). Estrogen receptor $\beta$ : the guardian of the endometrium. Human reproduction update, 21(2), 174 193. doi: 10.1093/humupd/dmu053.
Johnson, H., Torres, C. G., Carvallo, F., Duchens, M., \& Peralta, O. A. (2015). Endometrial expression of selected transcripts in postpartum of primiparous Holstein cows with clinical and subclinical endometritis. Animal reproduction science, 156, 34-39. doi: 10.1016/j.anireprosci.2015.02.007.

Kasimanickam, R., Duffield, T. F., Foster, R. A., Gartley, C. J., Leslie, K. E., Walton, J. S., \& Johnson, W. H. (2004). Endometrial cytology and ultrasonography for the detection of subclinical endometritis in postpartum dairy cows. Theriogenology, 62(1-2), 9-23. doi: 10.1016/j.theriogenology.2003.03.001.

Kimmins, S., \& MacLaren, L. A. (2001). Oestrous cycle and pregnancy effects on the distribution of oestrogen and progesterone receptors in bovine endometrium. Placenta, 22(8-9), 742-748. doi: 10.1053/plac.2001.0708.

LeBlanc, S. J. (2008). Postpartum uterine disease and dairy herd reproductive performance: a review. The Veterinary Journal, 176(1), 102-114. doi: 10.1016/j.tvj1.2007.12.019.

LeBlanc, S. J. (2012). Interactions of metabolism, inflammation, and reproductive tract health in the postpartum period in dairy cattle. Reproduction in Domestic Animals, 47, 18-30. doi: 10.1111/j.14390531.2012.02109.x.

Lee, I. I., \& Kim, J. J. (2014). Influence of AKT on progesterone action in endometrial diseases. Biology of reproduction, 91(3), 63-61. doi: 10.1095/biolreprod.114. 119255

Meikle, A., Bielli, A., Masironi, B., Pedrana, G., Wang, H., Forsberg, M., \& Sahlind, L. (2000). An immunohistochemical study on the regulation of estrogen receptor \$lalpha \$ by estradiol in the endometrium of the immature ewe. Reproduction Nutrition Development, 40(6), 587-596. doi: 10.1051/rnd:2000102.

Pascottini, O. B., Hostens, M., Dini, P., Vandepitte, J., Ducatelle, R., \& Opsomer, G. (2016). Comparison between cytology and histopathology to evaluate subclinical endometritis in dairy cows. Theriogenology, 86(6), 1550-1556. doi: 10.1016/j.theriogenology.2016.05.014.

Patel, B., Elguero, S., Thakore, S., Dahoud, W., Bedaiwy, M., \& Mesiano, S. (2015). Role of nuclear progesterone receptor isoforms in uterine pathophysiology. Human reproduction update, 21(2), 155-173. doi: 10.1093/humupd/dmu056.

Ramadan, A. A., Johnson III, G. L., \& Lewis, G. S. (1997). Regulation of uterine immune function during the estrous cycle and in response to infectious bacteria in sheep. Journal of animal Science, 75(6), 16211632. doi: 10.2527/1997.7561621x.

Robinson, R. S., Mann, G. E., Lamming, G. E., \& Wathes, D. C. (2001). Expression of oxytocin, oestrogen and progesterone receptors in uterine biopsy samples throughout the oestrous cycle and early pregnancy in cows. Reproduction, 122(6), 965-979. URL: https://pubmed.ncbi.nlm.nih.gov/11732992.

Saruhan, B. G., Sagsoz, H., Ketani, M. A., Akbalik, M. E., \& Ozyurtlu, N. (2009). Immunohistochemical detection of estrogen and progesteron receptors in the bovine uterus and their relation to serum sex steroid 
hormone levels during the follicular and luteal phase. Kafkas Univ Vet Fak Derg, 15(3), 447-454.

Sheldon, I. M., Cronin, J. G., Pospiech, M., \& Turner, M. L. (2018). Symposium review: Mechanisms linking metabolic stress with innate immunity in the endometrium. Journal of dairy science, 101(4), 3655-3664. doi: $10.3168 /$ jds.2017-13135.

Sheldon, I. M., Cronin, J., Goetze, L., Donofrio, G., \& Schuberth, H. J. (2009). Defining postpartum uterine disease and the mechanisms of infection and immunity in the female reproductive tract in cattle. Biology of reproduction, $\quad 81(6)$ 1025-1032. doi: 10.1095/biolreprod.109.077370.

Sheldon, I. M., Lewis, G. S., LeBlanc, S., \& Gilbert, R. O. (2006). Defining postpartum uterine disease in cattle. Theriogenology, 65(8), 1516-1530. doi: 10.1016/j.theriogenology.2005.08.021.

Sheldon, I. M., Price, S. B., Cronin, J., Gilbert, R. O., \& Gadsby, J. E. (2009). Mechanisms of infertility associated with clinical and subclinical endometritis in high producing dairy cattle. Reproduction in domestic animals, 44(3), 1-9. doi: 10.1111/j.1439-0531.2009.01465.x.

Smolen, A. J. (1990). Image analytic techniques for quantification of immunohistochemical staining in the nervous system. In Methods in neurosciences, Academic Press, 3, 208-229.

Stefanyk, V. Ju., Zavirjuha, V. I., Kostyshyn, Je. Je., \& Ivashkiv, R. M. (2010). Morfologichna harakterystyka endometriju neplidnyh koriv $\mathrm{z}$ vykorystannjam skanujuchoi' elektronnoi' mikroskopii'. Naukovyj visnyk L'vivs'kogo nacional'nogo universytetu vet- erynarnoi' medycyny ta biotehnologij im. S. Z. G'zhyc'kogo, 12(3(1)), 219-227 (in Ukrainian).

Stormshak, F., \& Bishop, C. V. (2008). Board-invited review: estrogen and progesterone signaling: genomic and nongenomic actions in domestic ruminants. Journal of animal science, 86(2), 299-315. doi: 10.2527/jas.2007-0489.

Sukjumlong, S., Kaeoket, K., Dalin, A. M., \& Persson, E. (2003). Immunohistochemical studies on oestrogen receptor alpha $(\mathrm{ER} \alpha)$ and the proliferative marker ki-67 in the sow uterus at different stages of the oestrous cycle. Reproduction in domestic animals, 38(1), 5-12. doi: 10.1046/j.1439-0531.2003.00383.x.

Turner, M. L., Healey, G. D., \& Sheldon, I. M. (2012). Immunity and inflammation in the uterus. Reproduction in Domestic Animals, 47, 402-409. doi: 10.1111/j.1439-0531.2012.02104.x.

Wang, H., Eriksson, H., \& Sahlin, L. (2000). Estrogen receptors $\alpha$ and $\beta$ in the female reproductive tract of the rat during the estrous cycle. Biology of reproduction, 63(5), 1331-1340. doi: 10.1095/biolreprod63.5.1331.

Williams, E. J., Fischer, D. P., Pfeiffer, D. U., England, G. C., Noakes, D. E., Dobson, H., \& Sheldon, I. M. (2005). Clinical evaluation of postpartum vaginal mucus reflects uterine bacterial infection and the immune response in cattle. Theriogenology, 63(1), 102-117. doi: 10.1016/j.theriogenology.2004.03.017.

Xiao, C. W., \& Goff, A. K. (1998). Differential effects of oestradiol and progesterone on proliferation and morphology of cultured bovine uterine epithelial and stromal cells. Reproduction, 112(2), 315-324. doi: 10.1530/jrf.0.1120315. 